\title{
78.
}

$015 \cdot 732.365: 012 \cdot 308.145 \cdot 1: 616003.821$

演崎氏耐酸性顆粒卜硅. 曹注射二依儿

Amyloidosis トノ關係ニ就テ

（䉜 2 報）

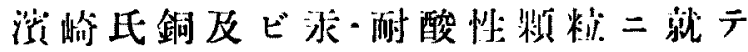

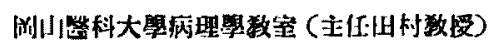

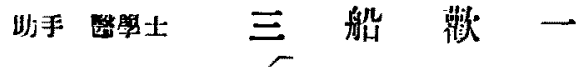

[昭和 13 年 1 月 22 日受䄸]

Aus dem Pathologischen Institut der Medisinischen Finkultint Oknyauna.

(Vorseand: Prof. Dr. Oio Tramura)

Über die Beziehung zwischen den Hamazakischen säurefesten Granulı und der durch Natriunsilikatinjektion erzengten Ainyloidosis.

\section{(2. Mitteilmmg)}

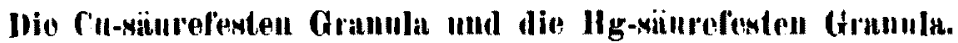

Von

Dr. Kan-ichi Mibuse.

Fingegangen ain 22. Januar 1938

Verfasser wünschte die Beziehung zwischen der Storung des Eiweißstoffwechsels und den säurefesten Substanzen experimentell zu uutersuchen und-weiterhin deu Zusammenhang der Amyloidsubstanz mit deu Zerfallprodukten der Nucleoproteide klar zu machen.

Über den Einfluß der Natriumsilikatinjektion auf die Hamazakischen aäurefesten Granula hat Verfasser die Resultate seiner tierexperimentellen Untersuchungen durch den Nachweis der Cr-säurefesten Granula in seiner letzten Arbeit mitgeteilt. Nämlich, lurch dauernde Injektiou der Silikatlosung ergibt sich in allgemeinen eine deutliche Verminderuug der Cr-säurefesten Granula, insbesondere in der Umgebung der Amyloid- 
substauz, und in der letzteren finden sich weder säurefeste Granula noch säurefeste Substanz. Verfasser hat demnach angenommen, daß die Nucleinsäure, die wichtigste säurefeste Substanz in den Abbauprodukten der Nucleoproteide, unmittelbar an der Entstehung der Amyloidsubstanz nicht beteiligt sein kann. Dabei gibt es aber noch eine Moglichkeit, daß nicht die Nucleinsäure selbst, sondern ihre weiteren Spaltprodukte (Purinderivate) eine gewisse Rolle bei der Amyloidbildung spielen kónnen.

Demgemāß hat sich Verfasser weiter mit dem Einfluß der Natriurnsilikatinjektiou auf die Cu-säurefesten Granula, welche hauptsächlich aus Mononucleotiden und Mononucleosiden bestehen, und auf die Hg-säurefesten Granula, deren Hauptbestandteile Purinbasen sind, beschāftigt. Die Resultate dieser Untersuchung sind, zusammengefaßt, folgende :

Die Cu-säurefesten, Hg-säurefesten Granula und das säurefeste Lipoid findet man nicht in der Amyloidsubstanz, welche durch die Natriumsilikatinjektion erzeugt worden ist. Die Cu-säurefesten und $\mathbf{H g}$-8äurefesten Granula zeigen auch eine deutliche Verminderung und sogar oft verschwinden sie in den durch die Amyloidsubstanz infiltrierten Geweben. Jedoch hat diese Verminderung der Cu-säurefesten Granula einen inuigen Zusammeuhang mit dem Ernährungezustand des Organismus; bei gut genāhrten Tieren tritt diese Erscheinung wur undeutlich zutage. In Gegensatz zu den Cr-säurefesten und Cu-säurefesten Grauula verringern sich die IIg-säurefesten Granula bei eineın günstigen Ernährungszustand ebenfalls sehr deutlich.

Aufgrund den oben genaunten Daten kann man wohl annehmen, daB sich weder Nucleinsăure noch Purinmononucleotide bis zu Puriubasen unmittelbar an der Anyloidbildung beteiligen konnen.

Während die braunen Abuutzungspigmente bei der Verhungerung des Kontrollversuches deutlich zunehmen, fiudet bei der experimentellen Silikatinjektion kaum eiue Vermehrung derselben statt. Die Abuutzungspigmente entstehen, wie sehon Hamazaki bestätigt hat, aus den endogenen sãurefesten Granula, welche Spaltungsprodukte des Kerneiweißes sind. Deshalb ist es unwahrscheinlicb, daß man, wie Gierke-Aschoff es tut, den Zellkernzerfall des betreffenden Organismus als eine der wichtigsten Ursachen der Amyloiderkrankung betrachten kanu. (Autoreferat)

\section{緒論}

演崎氏酎酸性顆柆二及ボス硅曹注射，影響

二就キジハ,第 1 報トシテ余ハ暴二「フ」而酸 性顆粒證明法二依ル菑騟的研究子發表セリ。

郎 F Nucleoproteide，主要分解座物タル核

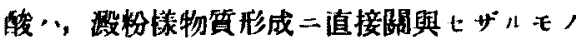

ナルコトタ證明七シガ，今间八更二核酸ノ分

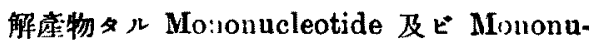
cleosirle 等子ま成分ト十七ル錩・耐酸性顆粒

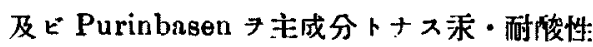
顆粒 子憸索，對象トシテ硅曹注射二依儿影響

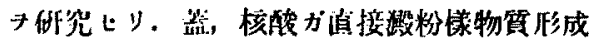


二寥與セザル易合二於テモ，其，分解㡾物夕

ル Purinderivate ガ之二關與スル事八有り 得バキガ故ナリ．而シラ耐酸性顆粒二八何木

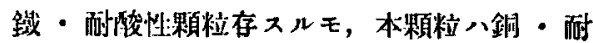

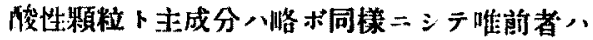
Mononucleotide 7 多量二, 又媵者、Mononucleoside 7 多量二合有スル，差異厂ル，

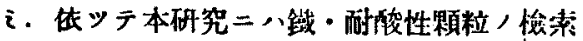
キ省略セリ。

\section{蒉鸦方法}

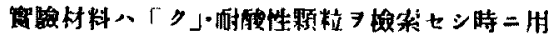

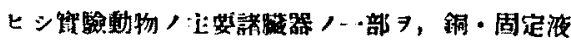

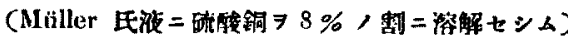

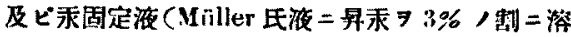

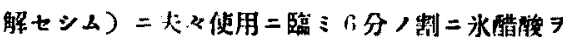
加一タル㳖二デ固定セり、斯儿固定材料へ「り・

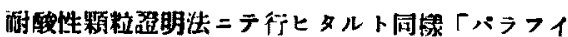

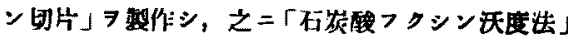

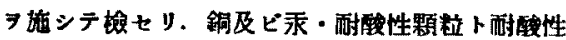

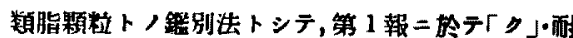

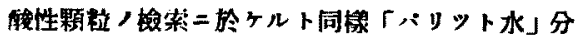

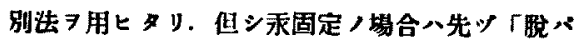
ラフイン後」ルゴール氏液二牛時間浸请シ，次亞

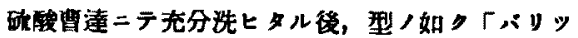

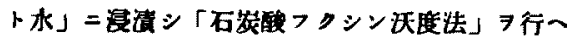

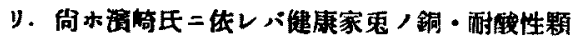
粒八「パシシト水」分別ニヨロテ完全二溶解サル ルコト少ナク，星色诚退二止マル事多シト云7. 其

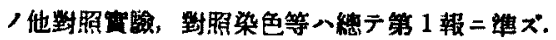

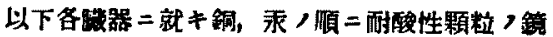
铪所見习䢞ベシ。

\section{賈驗成績}

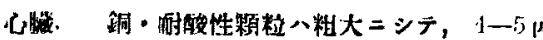

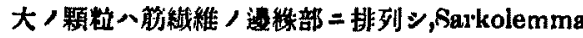

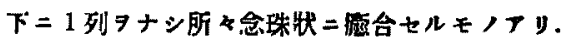
1 部八 Sarkolemma，外表二附着ス. 小ナルモ，

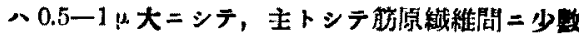

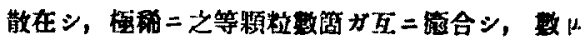

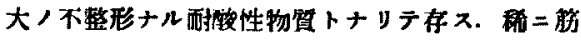

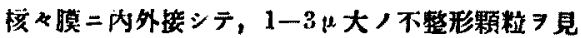

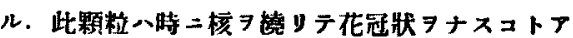

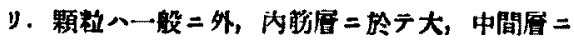
於テ小ニシテ，「ク」・而酸性顆粒二比シ類固形 7

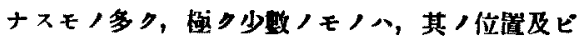

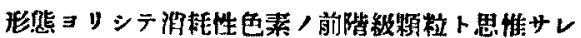

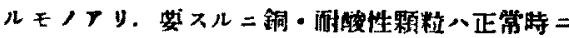

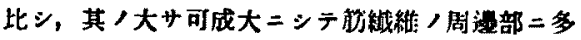

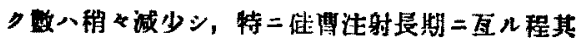

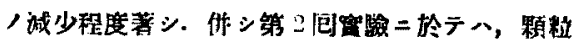

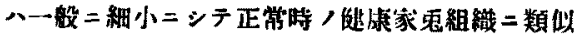
シ，诚少程度著シカラズ。

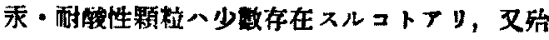
ド跟メ得ザルコトフリ．而シテ少教残存セルモ， 二於テハ, 筇原織維,間二 $=0.5 \mu$ 以下゙，粉末状，顆

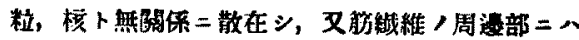

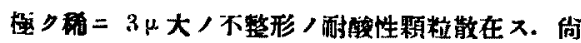
木間留及ヒ血管壁二於テ八紫堇色，耐酸性物留方

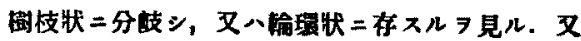

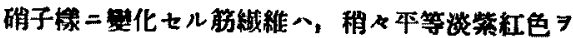
嘋ス. 而シテ永・耐酸性颗粒そ，亦娃曾注射／長 期二互レルモ程減少習シ。

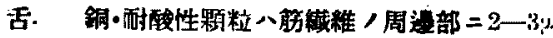

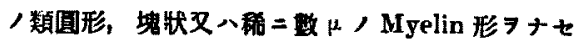
几耐酸性顆粒稍心多教存シ，其ノ大ナルモノ八多

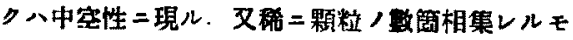

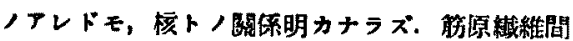
二介在シテ大鮟 $0.5-1 \mu$ 大類圆形稍《均整习得

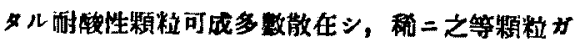




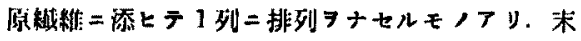

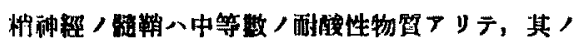

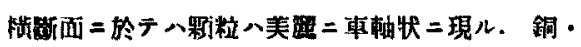

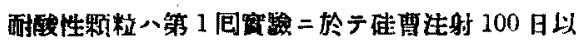
上/長期二及ー゙ルモノ二於テ八, 可成娍少セルモ

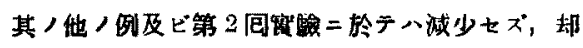

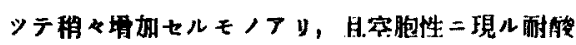
性颗粒多シ.

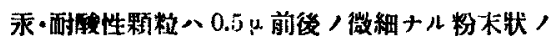

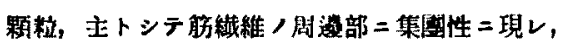

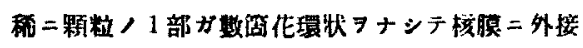

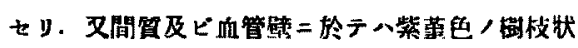
二分肢セルモ， 叉八输環狀／酎酸性物行敬在性

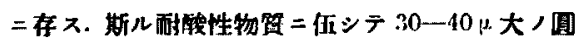

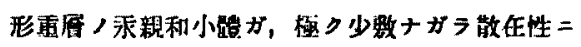

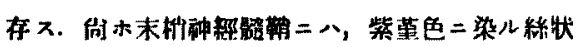

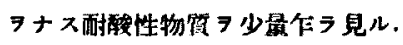

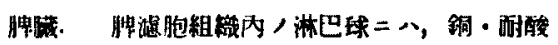

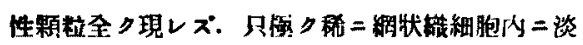

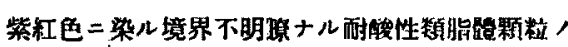

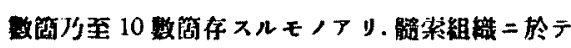

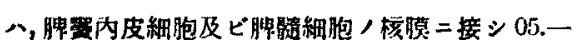

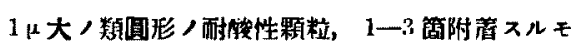

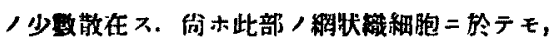
胞胞ノ夫類似セル如キ組楊像

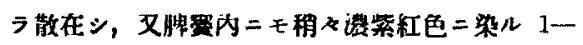

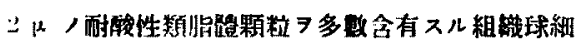

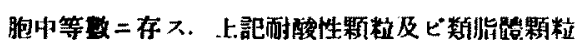

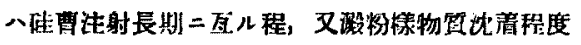

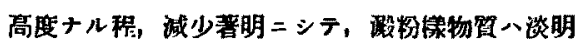
平等二垷レ全ク颗精

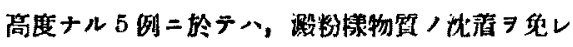

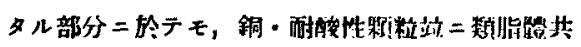
二全り消失セり.

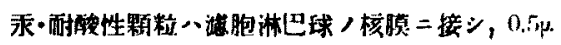

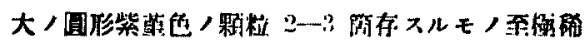

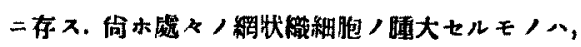
酧酸性類脂能 7 其

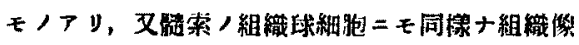

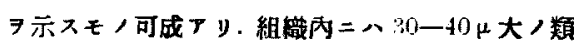

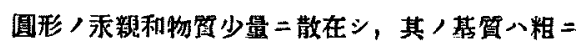
シテ網状或八野翞状二現レ色鮮明ナラズ. 以上，

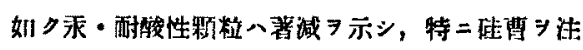
射スルコト屒期二互レルモノ程减少シ，澱物様物

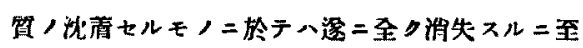

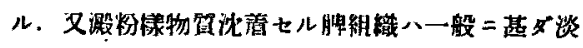
明二染儿.

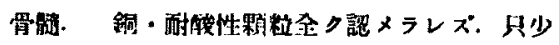

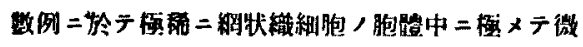

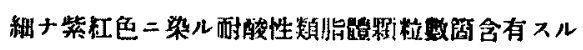

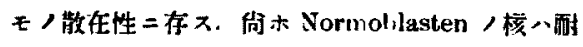

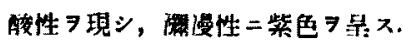

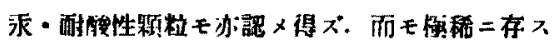

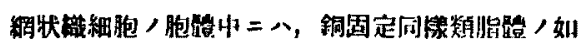
キ颗粒存シ「ハンット水分別二テ淮失セズ，却\% テ稍く大ナル美国ナル顆粒トシテ現儿。又處を二

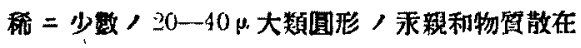
シ，其，基繁八粗二シテ絧狀或八颗柆狀二現儿。

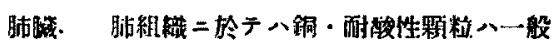

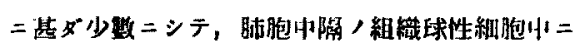

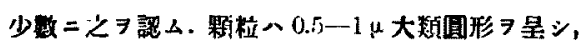

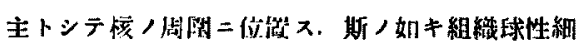

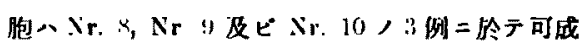

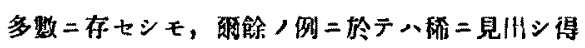

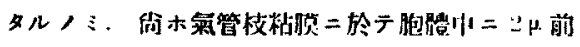

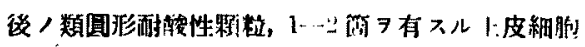

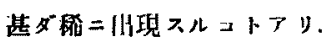

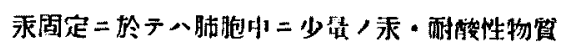

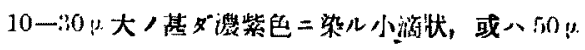

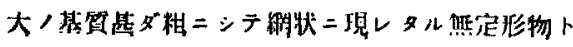


シテ周定サル，又肋膛下／肺胞中淂，中二存 ス組

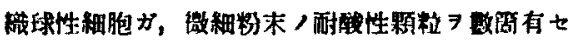

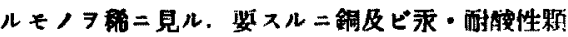

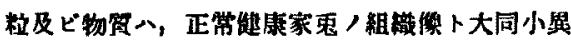

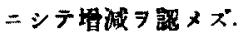

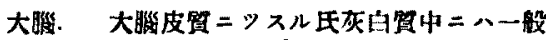

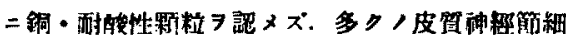

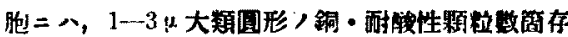
シ，大ナルもノ人多っ八中空性二現儿。斯儿颗柆

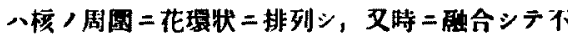

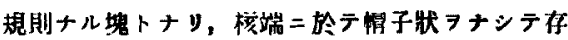

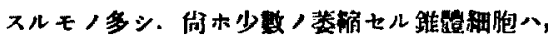

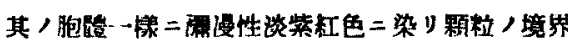
明能 7 缺 ク。

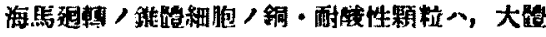

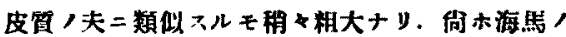

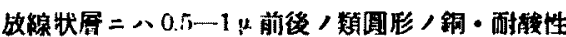

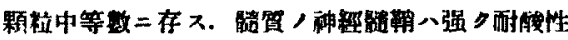

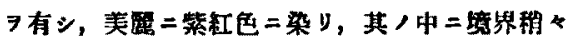

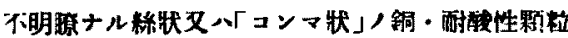

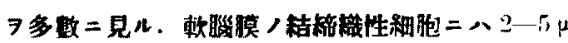

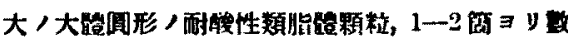

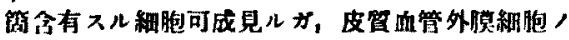

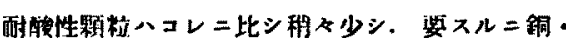

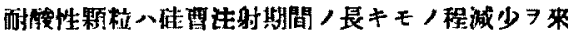

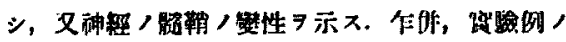

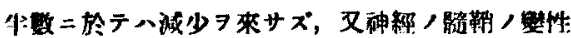

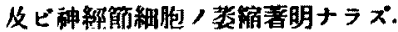

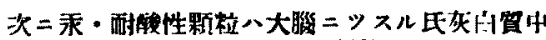

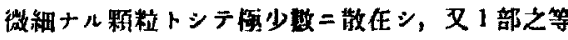

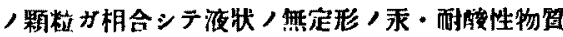

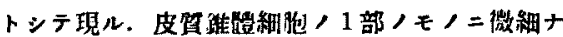

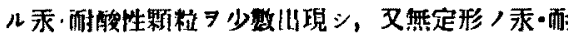

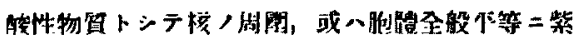
革色二現儿樹枝狀突起，㮛部二同物管，果情スル

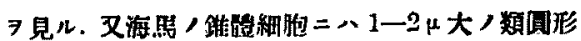

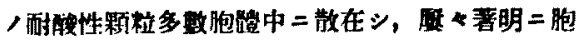

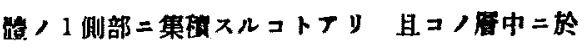

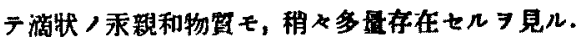

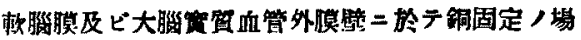

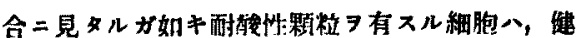

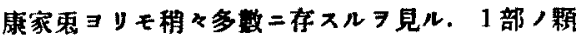

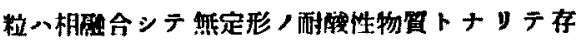

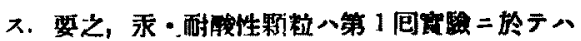

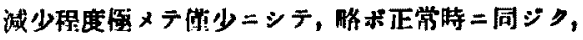

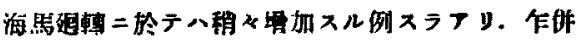
第2回二於テ八顆粒八緗小ニシテ，目可成诚少著

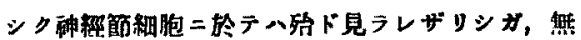

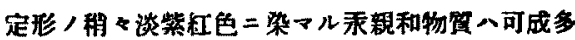
散在シ正常時 $コ$ ソ租々多キガ如シ.

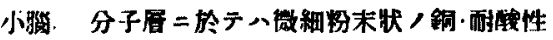
颗精中等数二存シ，之等，颗粒、深展二近ヅ

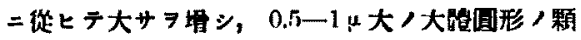

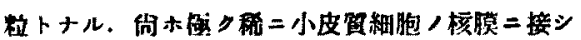
租《粗大ナル不整形ニシテ是な中空性二現ルル

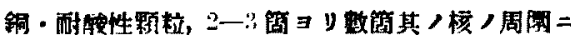

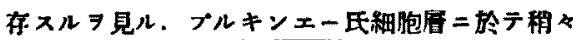
多數ノプルキンェー氏緗胞ノ胞娟中二，特二其，

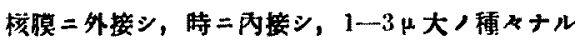

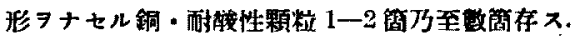

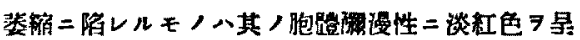
ス. 颗粒屋二於テハ1一2

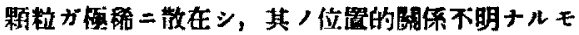

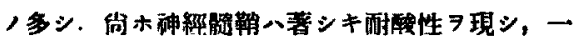

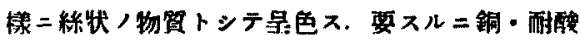

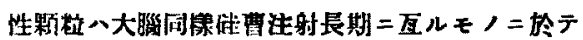

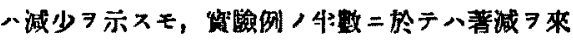
サズ:

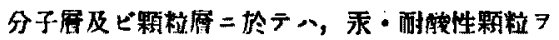
謁得ズ、ブルキンエー氏細胞八其，胞比淡紫紅 


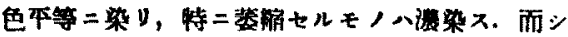

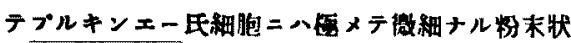

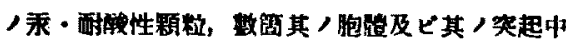

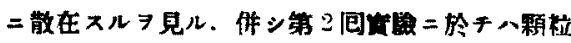

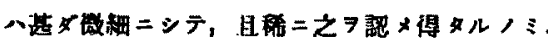

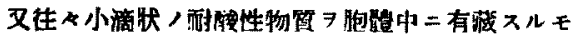

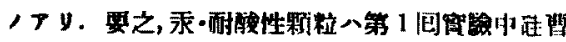
注射長期二互レルモ。二於テ八可成娍少セルモ，

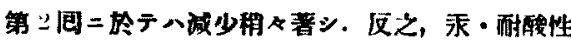

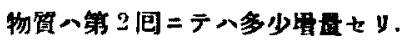

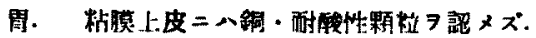

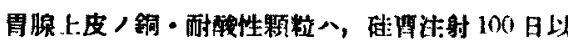
上，長期二互レル少数国二於テ八租々娍少

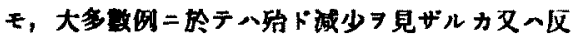

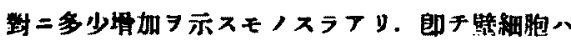

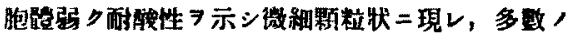

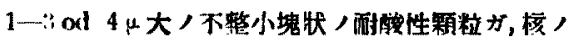

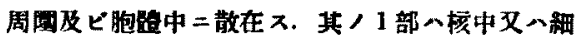

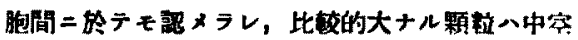

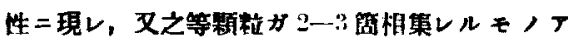

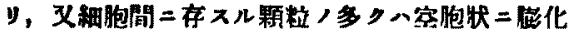
セリ. 主料胞二於テ八顆精稍く少ク且小ニシテ, 其，胞错八透明ナリ. 其／他／部位二顆粒 7 見 x".

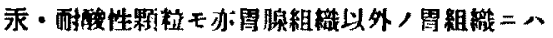

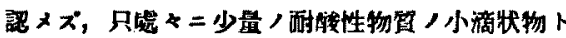
シテ固定サルル

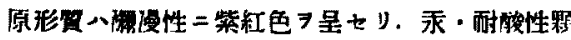

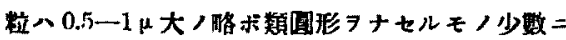
存シ，主トシテ核ノ周图及ビ其ノ內部二出晛ス，

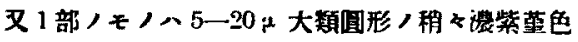

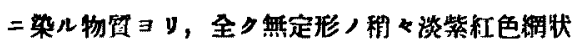

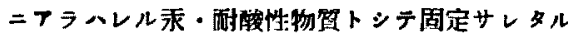
モノフリ．主細胞八辟細胞二反シ淡明ニシテ耐畒

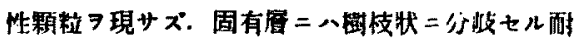

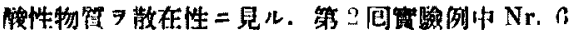
Nr.7 及ビNr.8，3例二於テハ，上記䞂酸性顆 柆八可成诚少シ監ドと7認入得ザリキ。

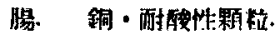

十二指㻛. 晹內容物中二八大小不同，滴状

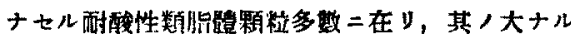

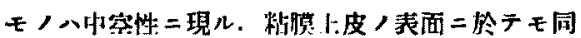

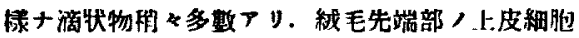

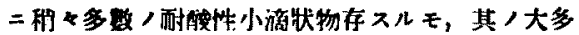

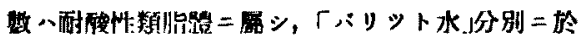

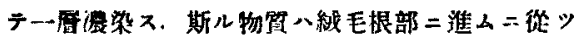

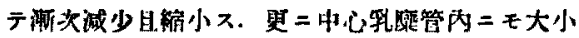

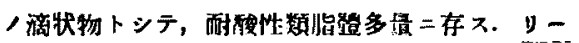

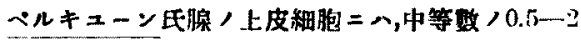

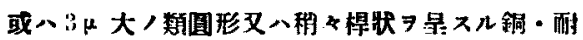

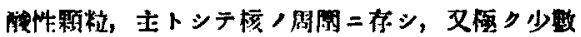
ハモノ八核中二存スルョ見ル、ブリンンホル氏腺

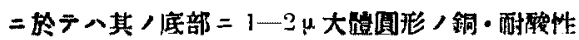

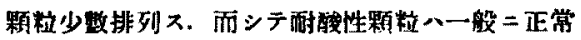

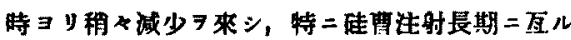
モ,程诚少程度著明ナリ。

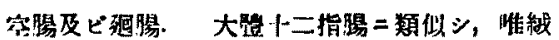

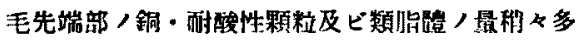

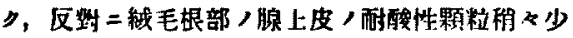
シ.

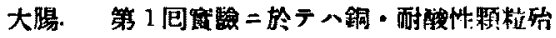

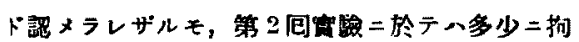

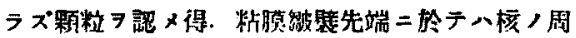

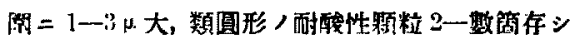

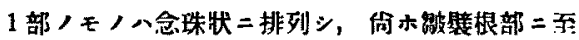
ルニ從七顆粒八減少シ，上皮細胞，底部二近ク排

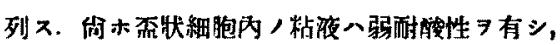

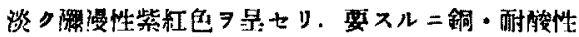
顆盖へ一般二可成娍少著明ニシテ，特二注射，展 期二五儿モノ二於テ然シ. 
承・耐酸性颗粒.

十二指䐎二在りテン各例二於テ相異甚シク，多 数存スルモノョリ全然詪メラレザル列二至ル迄，

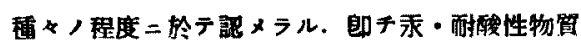

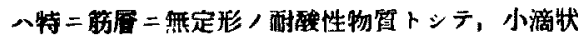

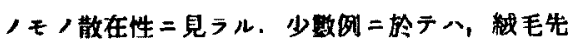

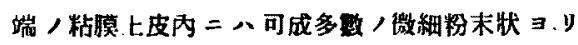

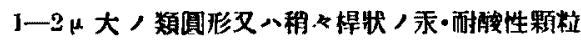

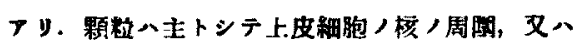

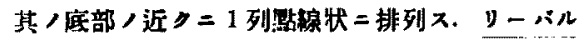

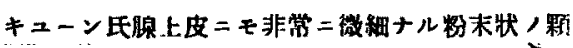
粒胞能中二散在シ，顆柆八固有膜二近》。皮底部

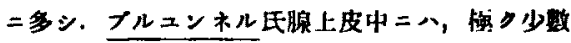

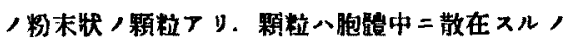
ミナラズ，其，腺整中二移行セり卜思ハルモく

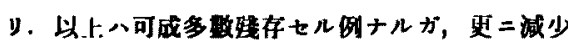

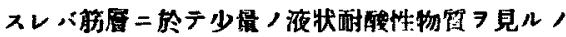
: ニシテ，終りニへ全り酎醅性物留习訅入得ザル 二古ル.

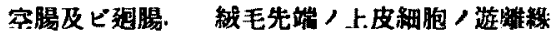

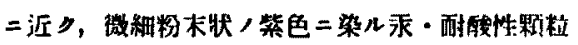

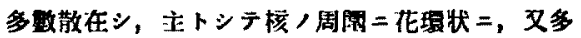

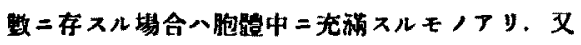

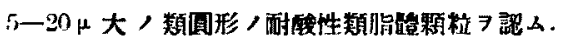

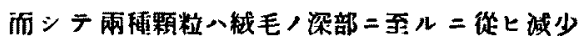

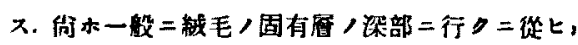

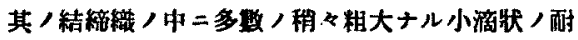

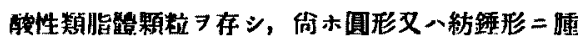

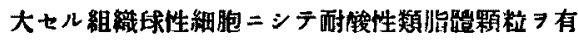

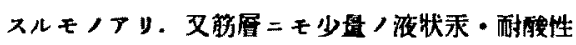

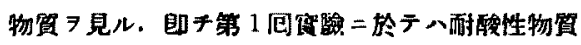

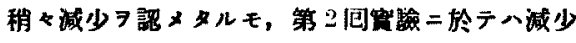
セズ、却ッテ增加セルモノフ如シ

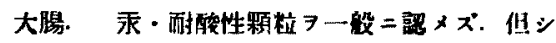

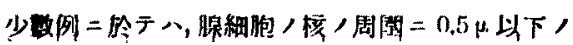

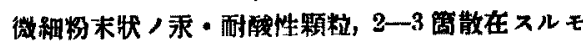

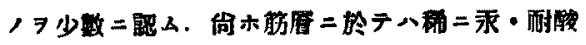

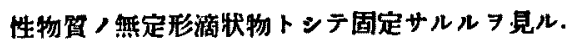

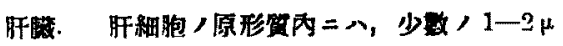

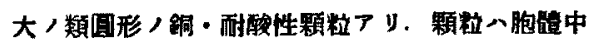

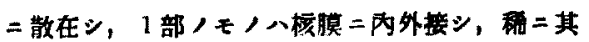

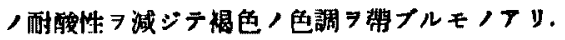

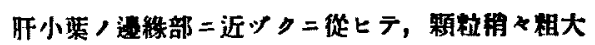
トナリ不整形习是スモ/多》，其，整モ多少䐬加

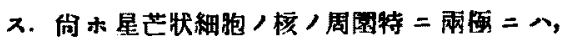
$1-3 \mu$ 大八銅・耐酸性顆粒少黣存ス. 又睡大七儿

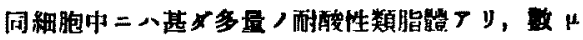

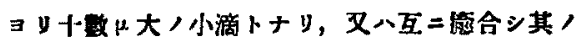

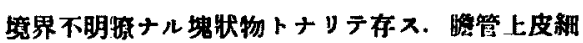
胞中二八，主トシテ榕，周网二物末狀，耐酸性颗

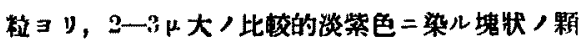

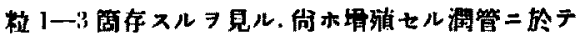

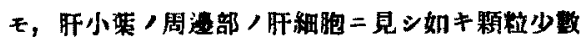

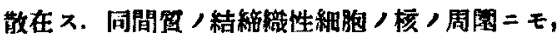

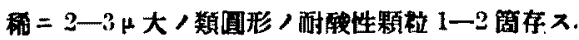

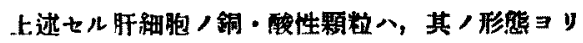

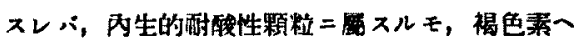

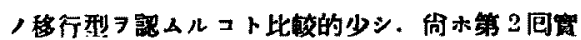

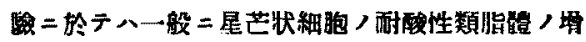
著シキモ，酎破性顆粒八减少ス，注意スベキへ

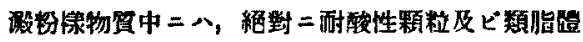
ヨ見ザルコトナリ。

永・耐酸性顆粠恤明沠 = 在 リテ

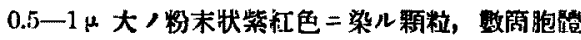
中ニ主トシテ中央部二散在シ，稀二核獏に接シテ

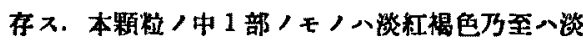

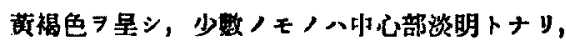

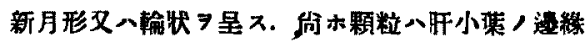

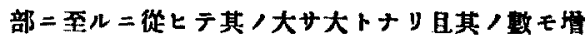

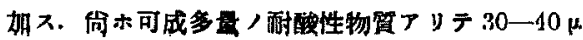




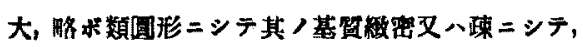
粘状二淡染スル小锗トシテ固定サレ署明ナル耐酸

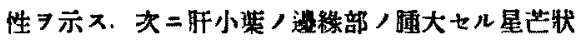

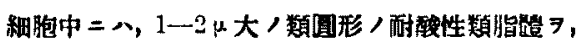
胞徣中二多量二合有七ルモ，散在ス，又ダリンン

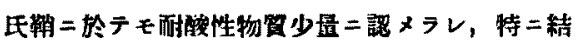

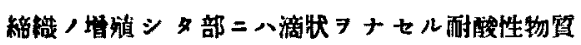

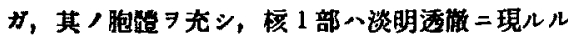

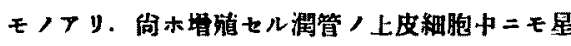
艺緇胞二見かルガ如キ颗粒

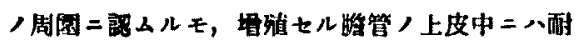
腰性顆䊉

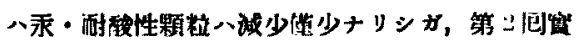

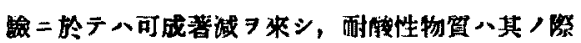
比較的多㭴 $\times$ 佰.

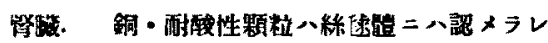

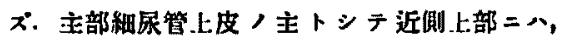
0.5一3. 大類圆形又、不整形ニシテ,大ナルそ， 目电中空性二現儿几耐酸性顆粒中等㩆二散在シ，

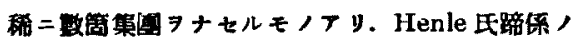

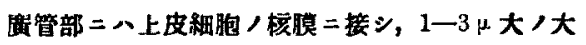

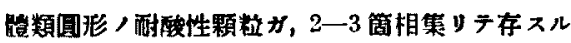

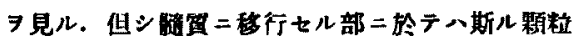
八㘿加剒大シテ、形又不整形ノモノ多ク，大ナル

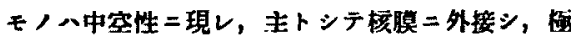
稀二核ノ內二モ存スル

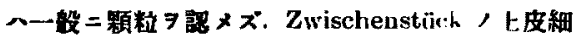
胞原形留、理漫性二紫染シ，其，耐酸性顆粒一赫

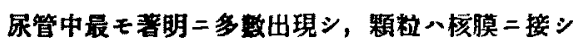

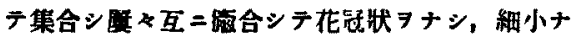
儿颗粒八底部二多存ス，潤管上皮，顆粒，分布

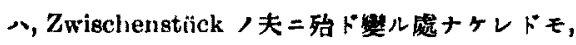
其ノ数及ビ大サョ著シク少多，且組胞原形留八淡 明ナリ. 集合管

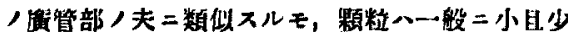

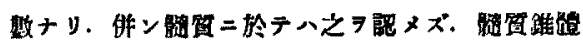

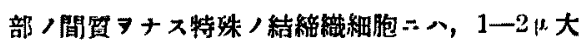

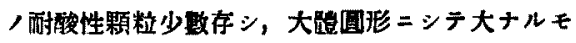
八ハ中空性二現ルルモ,ナリ. 本顆粒ハ一般二巴 租々谈，主トシテ核膜二接シテ存入。份小 Bow

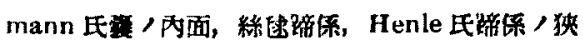

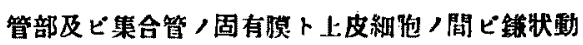

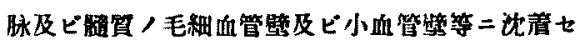

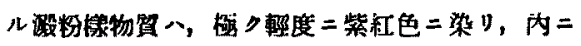

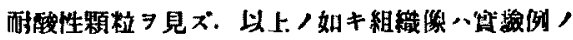

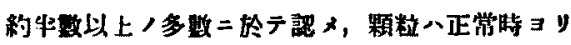
稍《增加シ，殊二Zwischenstiirk 及ビ潤管上皮二 菨明ニシテ，Zwisehenstïck 八絹尿管上皮，肥厚

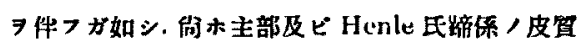

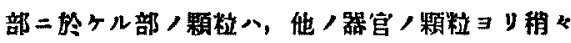
其，染色度弱》，谈紫紅色二染儿。併シ約 100 日

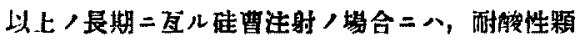

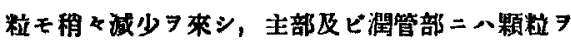

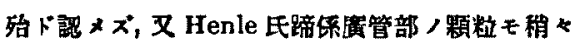
小ナy.

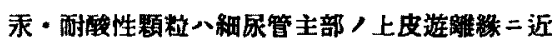

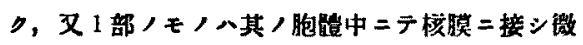

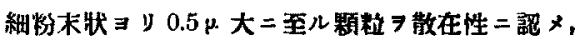
又可成多量，湬・耐酸性物算ナリテ無定二固定形 サル 一般二其ノ大サ $0.5-1 \mu$ 大 / 類圆形顆粒力可成

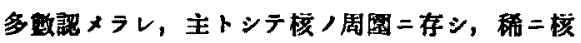

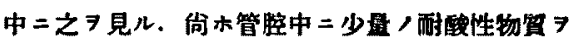

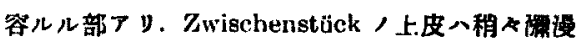

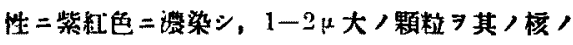

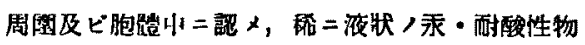

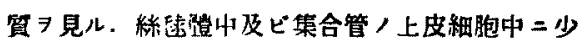

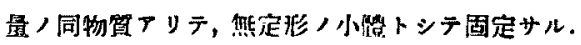

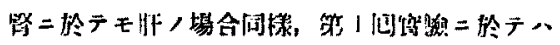

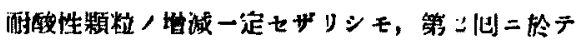




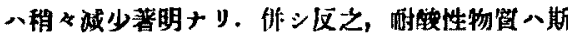
カル列二於テ八他例 ヨリ七多星ナリ。

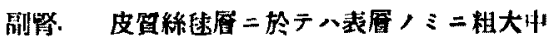

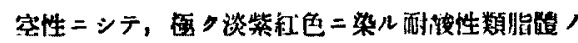

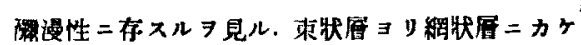

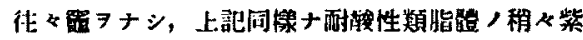

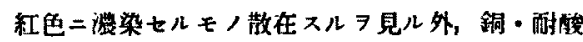

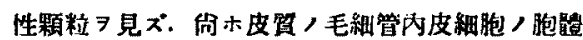

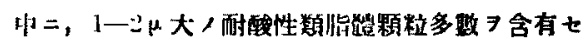

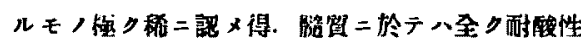

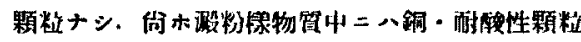

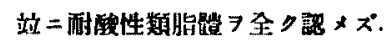

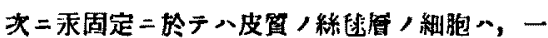
般二弱形较性

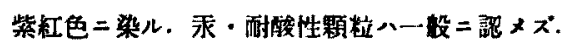

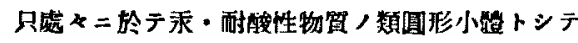
固定サルル

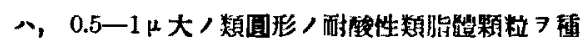
乘ナ程度二含有スルモ，可成多政散任ス。斯儿顆

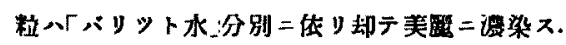

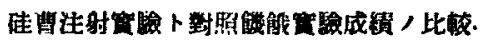

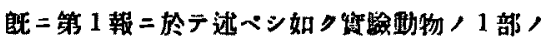

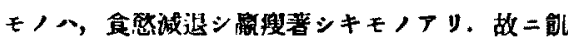

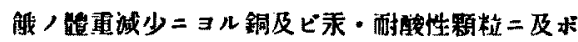

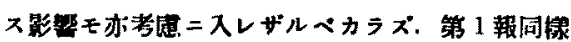

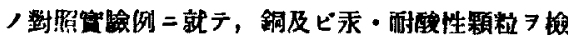
シタy. 其/成績，大要头，如シ。

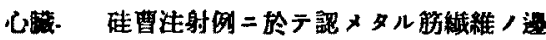

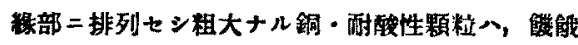

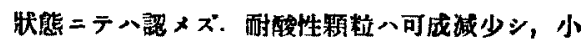
ナル顆教八被色巴調ヨ帶ブモノ多キハ注日スベキ

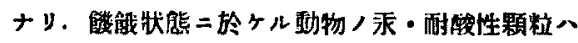

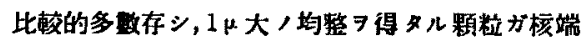
=2-3䇠ッッ集合シ,一般二內生的酎酸性顆粒，

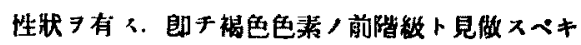

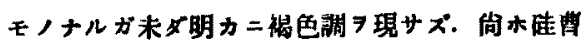

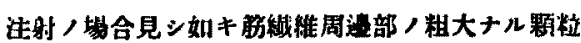
八存セズ.

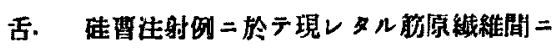

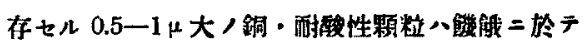

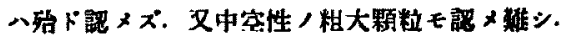

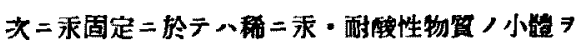
ナシテ閔留二散在スルノミニシテ夏ド顆粒トシテ 認メラレズ.

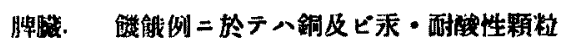
全ク消失ス. 又䞒及ビ湬固定，何レ/场合モ，組織

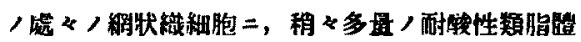

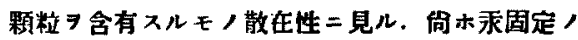

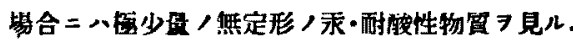

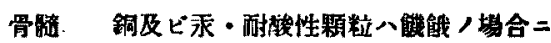
モ出現七 $x^{\circ}$.

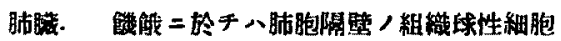

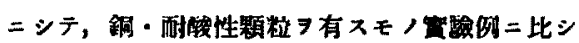

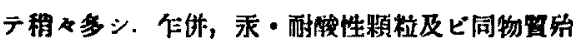

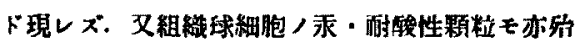
ド見ズ.

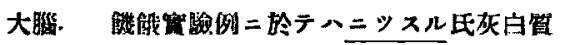

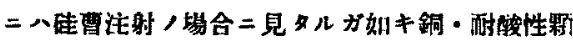

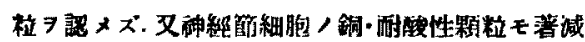
ヨ示シ，胞體中二八㱠ド顆柆 7 認 メズ，只核膜二

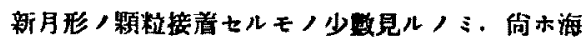
馬人神經飭細胞二於テモ斯儿絧胞多少多キノミ。

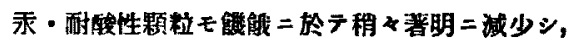
份木滴状 $カ$ ナル耐酸性物曾

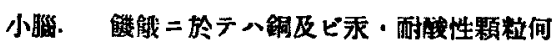

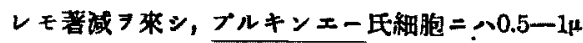

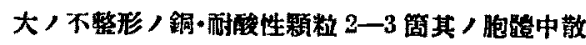

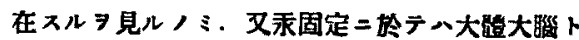
大盖ナシ。

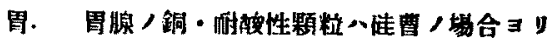




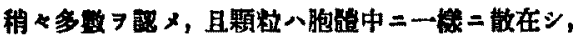

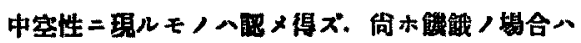
胃腺 梁部二至ル二终七，顆粠ハ絹少トナリ且少

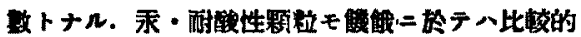

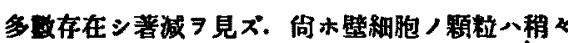

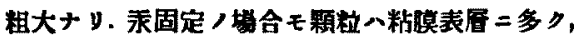

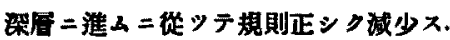

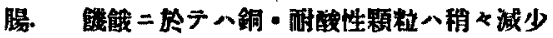
シ，小腸ノ䄉毛先端部二メ主トシテ中空性二現レ タル 1-5 $\mu$ 大，類脂能顆粒中等数及ビ酎酸性顆

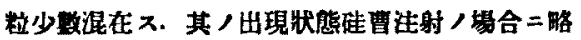

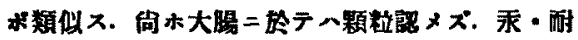

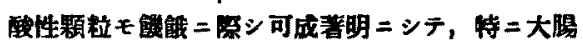

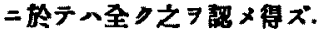

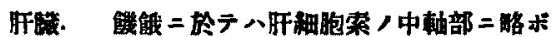

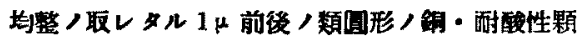

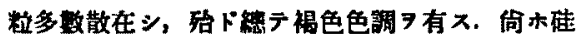

曹注射二見シ如キ星せ状种胞肉及ビ其ノ他八耐酸

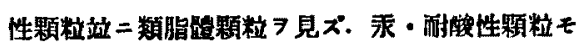

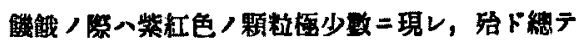

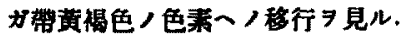

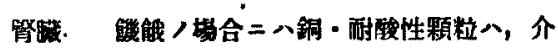

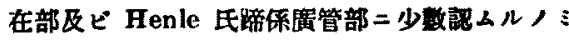

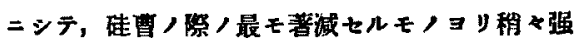
ク娍少シ且和小ニシテ中空性二現レタルモノ全ク

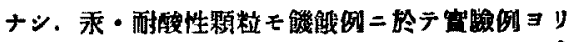

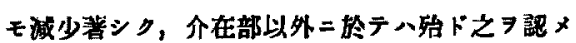
x.

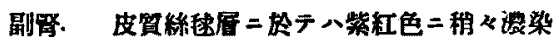
スル小ナル類脂能顆粒可成多数存シ，東狀抟及ビ 誷狀居 ニテハ面ク淡ク紫紅色二染儿境界不鲜明ナ

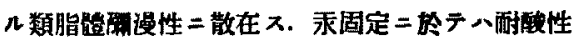

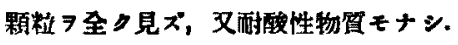

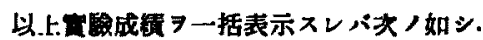

銅・耐酸性顆粒

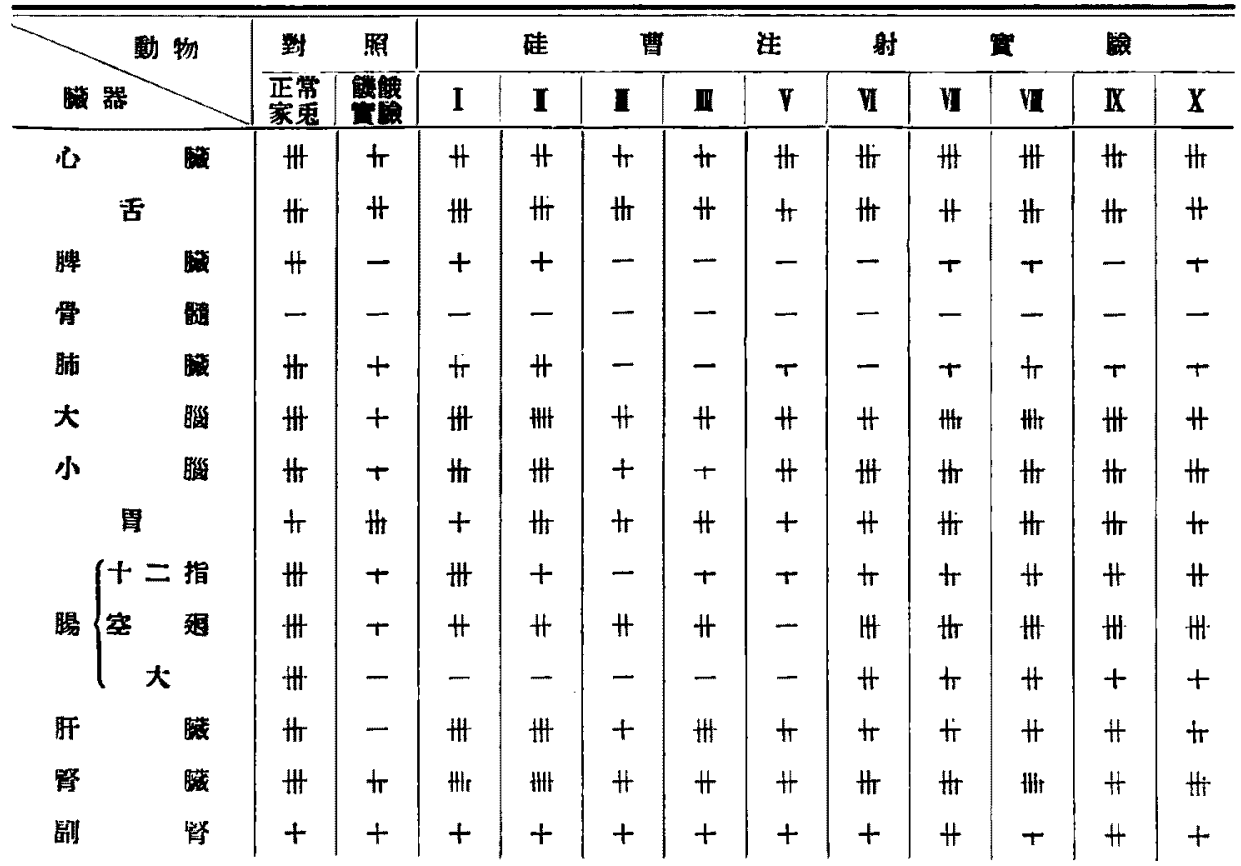


手・酎 酸 性顆 粒

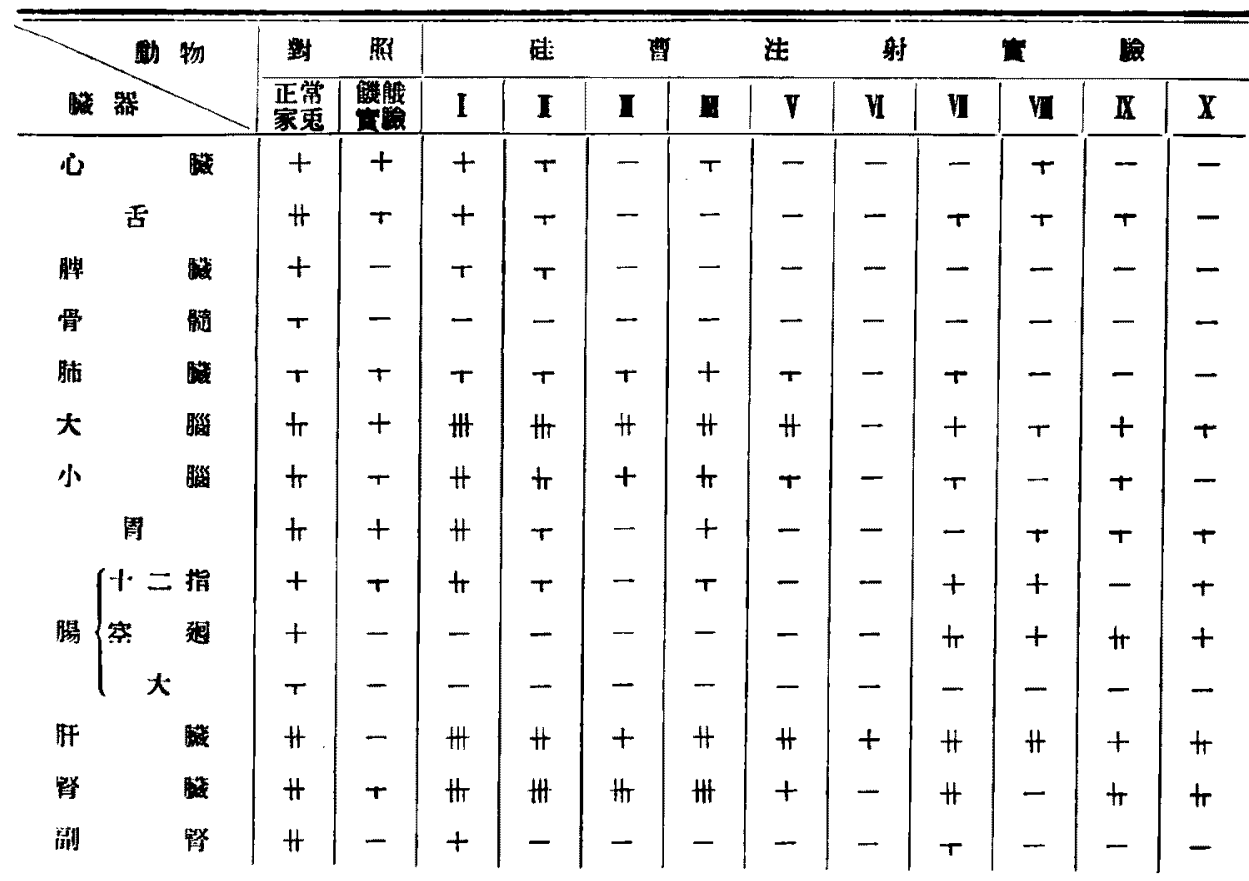

總括. 考按

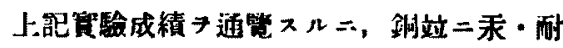

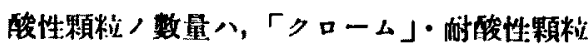
二比シテ動据梢々著明ナリ．斯心偭向八正常 動物二於テモ認メラルルモノナルガ故二，箩 シ止ムヨ得ザルモノナル可シ。除・耐酸性顆 粒八硅曹注射二ヨリラー般二八減少スルモ， 「クローム」・耐酸性顆粒二比 三テ娍少度左程 著シ力ラズ．就中，第 1 回曾騟例二於テハ, 一 般二顆粒，堿少稍々著明ナルモ，少数例二於 テハ1,2 的器，同顆粒八例外的七り. 又第 2 回曾騟例二於示，各例共多少二拘三 ズ錩・耐酸性顆粒/減少み來七ルモ，減少度

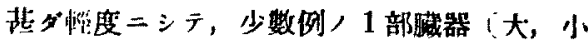

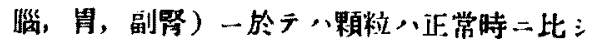

宁增加をり。

又秉・耐酸性顆䉼二就テ检スル二全體卜三

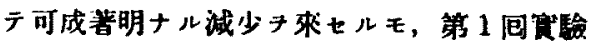
例二於テ 1 例人ミ正常僄习有シ，他心總テ

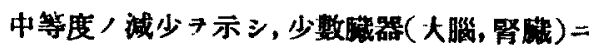

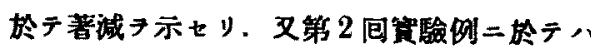
全例二通ジテ永・耐酸性顆粒ノ著诚尹來七り。 耐酸性顆粒八演㥓氏，組織化學的研究二依 レパ, 一般二多少二拘ラズ類脂體 7 含有スル モノニシテ，微細ナル顆粒二在りテ八䊼織军 的二類脂脰 確登シ得ザルモ,フルモ，化學

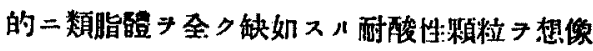
スルコトヌ得ズト云フ。但, 而酸性顆粒二合 有サルル類脂體・, 從來知ラレタル類脂䐺 卜 異ナリ，耐酸性顆粒固定法以外，固定法二亏 
八證明シ得ズ. 郎チ耐酸性顆粒，證明サルル 時ミミ之二合有サレテ出現シ得ルモノナリ。

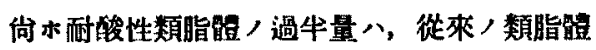
固定法ニョリテモ固定シ得ルモノナルモ，其 , 1 部モ亦酎酸性顆粒固定法, $i=ヨ$ ソテ固 定サルルモノナリ.

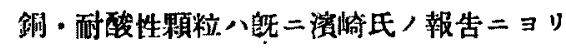
テ明カナルガ如ク，家鬼二在ソテハ4 程，耐 酸怡顆粒中最モ多量，類脂醩 尹合有スルモ， ナリ. 從ッテ住漕注射二際シテモ期・酎酸性: 顆粒證明法二在りテハ, 賞該動物組織，類脂

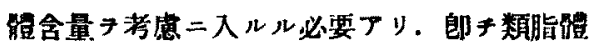
合量豐富ナル組織二於テハ，類脂體含量僅少 ナル組織二於ケルョリ, 墕・面酸性顆粒，固 定容易ニシテ, 且耐酸怛物質自身，量が等シ

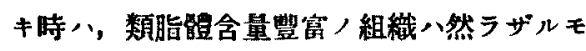
ノ二比シテ呈色性著明ナルガ故二，顆粒八易 ク檢出三得ルモノナリ。

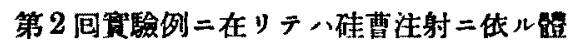
重減少著明ナラズ，1部ノモノ二於テハ反ッ テ肥涩をルモノスラアリタルコトハ, 第 1 報

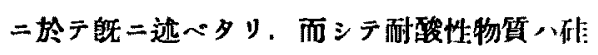
曹注射二ヨリテー般二減量スルコトハ, 前包 及ビ今间，實驗成績二徵シテ薙七ナキそ，第 2 回實驗例二於テ，耐酸栍顆粒，減量著明与

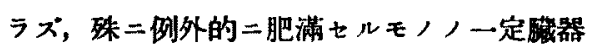
ニ在ソテハ、正常時ョリ顆粒㙁加セルモノス ラアリ. 而シテ斯クノ如キ誉器二於デ，同 時二對酸性類脂能モ亦正常時 $コ$ 增加七ルコ

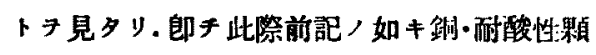
粒卜類脂體，相互關嗤，在りテ存セシコト八 想像二難カラズ. 而シテ此場合（毁千第 2 回

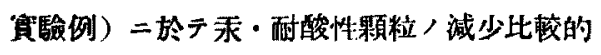

著明ナル八，本顆粒八㛠・衬酸性顆精二比三 テ類脂䝑ト，相互關係左程塞渱ナラザルタィ 類脂體，多宾二餘り支配サレズ，硅曹注射， 值接, 結果トシテ起ル各種耐酸性物蜇，全般

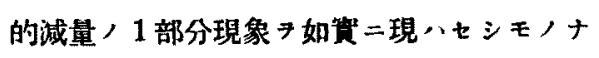
ルベシ.

第 1 回筫驗二在リテ動物ハ一般二嶡瘦 シ類 脂體著減七シが故二, 铜・耐酸性顆粒八前記 事㭊卜八反数二周定サレ難ク，且固定サレタ ルモ，モ，酎酸性類脂唱，含量少キタ丈呈色 性汹微ナルタメ，之尹檢出三難キモ，ト說明 シ得べシ。妶二注意スペキ心從來，類脂䁗研

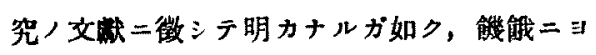
リテ類脂體ハ必ズシモ減量セズ，1 部八正常 時, 狀態 7 保子，叉1部八正常時ヨリ增加ス

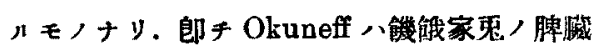
，網狀队皮細胞二，文同氏及ビ Erdheim 八

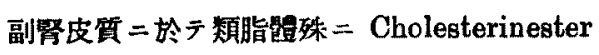
，沈着スルタ報告シ，其，量八正常時，狀態 ト異ナラザルカ，及ハ反ッテ堽加七り卜，叉 Traina, Laudau, 川村, Karwicka 䈔八觯

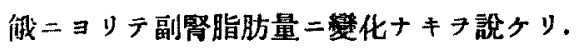

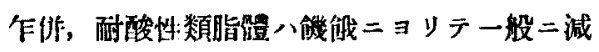
少ヨ來スモノナルコト，小西氏赛驗及ビ余， 對照算驗二於テ明力ナり，值曹注射曾驗例卜

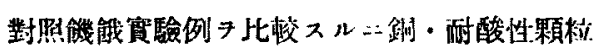
ニ在りテハ常二前者二於テ著シク多かリシモ 录・酎酸性顆粒二於テ八前者, 2 例，三後者 ヨリ多かリシノ

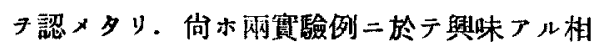

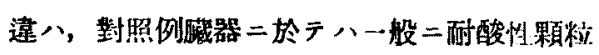
，褐色々素人，移行鮴明嘹ナリシ二反之，鲯 驗侧二於テハ本所見著シカラザリシコトナ 


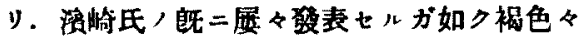

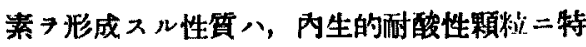
有ナルモ’ナリ。從ツテ硅曹注射赛驗例八對 黑僟解例二比シテ, 內生的耐酸性顆粒，發生 少キモ，卜見做スキ得ベク，引イテ，軆細胞

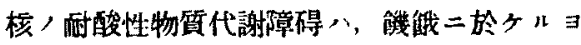

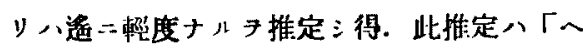
マトキシリンニエオシン染色」ニヨル兩種筫

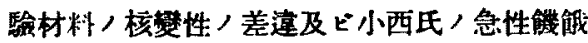
實驗成績二徵スルモ，多分二䓝然性

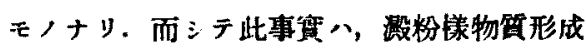
が䋚胞核崩壤卜重大ナル關㐿ニナリトナス Gierke-Aschoff，說二有利ナラザル所見タ ル八暻七タ容レザル所ナリ。

次二注意スベキ八顀驗動物中蒈ダ桱度ナル

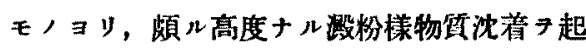
七ル二拘ラズ，何レ，例二於テモ組織細胞核 八耐酸性變性ヨ認メザルコトナリ．勿論細胞 核中及一核瞙二應着シテ微細ナル銅及ビ承・ 耐腹性顆料ノ存七ミコト屡々ナりミモ，斯， 如丰所見一既二生理的二存スルモノニシテ，

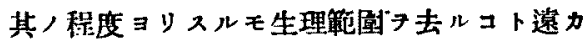

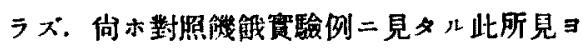
リ，透二桱度ナリ。

头二組織內二沈着七几涮粉樣物質自身二就 キテ，「石炭酸フクシン沃度法」ノ成績フ精 查スルニ,「ク」・耐酸性顆经同梂, 總テ，場

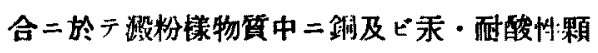

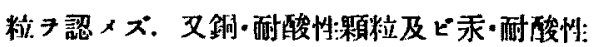
顆粒卜密接ナル關䋆タ有スベキ, 而酸忧類脂

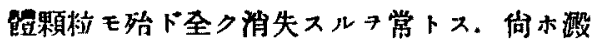

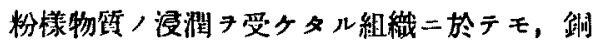
及ビ永・而酸性顆䊉減少稍々萃シク，屡々全ク
消失スルモノフリ，文耐酸性類脂鳢八通常著

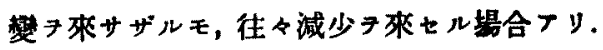
但，铜固定子施サレタル組織，耐酸性類脂體 八旰，脾二於亏激㸮樣物質，沈着高度ナル例 ニ在りテモ，倘水多量二存スルコトアリ．澱 粉漾物犋卜直接接七ザル，當該動物，器官組 織，踢及ビ我・酎酸性顆敉モ亦一般二減少 シ, 其，減少度，大約例曹注射，期間二正比 例シ，溊枌栐物質，量二反此例シテ現ルルモ 多:。

余，第 1 報告:於テ，核蛋白分解产物，澱 枌漾物質形成二寥與スルヤ否ヤ二就テ論シ，

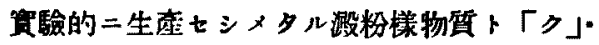

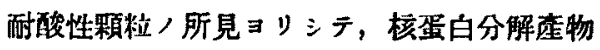
中，重要物質タル核酸，之二直接參與スルコ トナキタ論ゼリ。而シテ今回，實驗ニ於テハ, 核酸, 分解座物夕ルMononucleotide 及ビ Monouucleoside 7 主成分トスル釗・耐酸性 顆粒及ビ Purinlsasen ヨ主成分トスル泉・耐 酸性顆粒，亦既粉樣物質形成二參與スルコト ナキタ證明シ得タリ. 從ッテ核酸八核酸りレ 自身二於テモ，又核酸分解浾物ノ形ニ於テモ 激粉㨾物質形成二参與七ザルモノナリ。

份木村时・吉川氏等二依り澱粉漾物䆩中二, 類脂體/證明シ得ルコトタ報告サレタルコト. フルモ,余，賽驗成結二於テハ少クトモ，耐酸

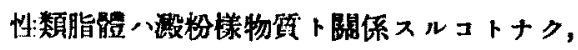

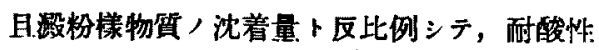
類脂體，減量スルッ認ハタリ。從ッテ耐酸性: 類脂體モ亦激粉聪物質形成二直接關與スルコ トナキモノト信ズ。

倘木余八第 1 報二於テ既二透ベシ如ク，動 物情核酸子主成分トナス「力」酎酸性顆粒八, 


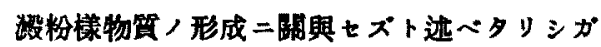

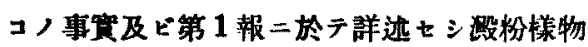
筫成因二對スル先進諸氏等・研究タ綜合シテ 考察ス儿時八，核酸，分解産物夕ル Purinmononucleotide 郎 A Adenylsäure, Guanyläure 及ピ Purinmononucleoside 䬦 $\neq$ Adenosin, Guanosiu 更二是レガ分解セル Purinbase 郎f Adenin, Guanin 等, Purinderivate 八, 澱粉樣物算形成二與與 コトハ, 通常有り得可カラザルモ，卜斷定ス ルモ䛇リナカル可シ.

\section{結敦}

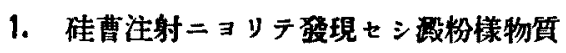
中二八，銅及ビ永・洏酸性:顆粒站二耐酸性類 脂體フ認メズ・

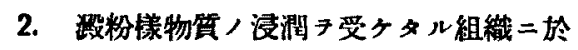
テハ, 銅及ビ承・耐酸性顆粒八減少子来シ, 屡々之等ノ全ク消失スルテ見ル。

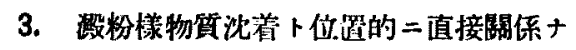
キ部位。在りテモ，铜・酎酸性顆粒ハ一般二
減少スル傾向タ示スモ，本現象八個體八㮡食

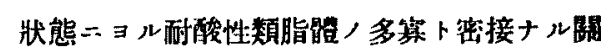
係ヲ有三，肥浦七ル動物二於テ八澱粉核物質 沈着症著明ナル堨合モ，銅・耐酸性顆粒減少 ダーザルモノフリ.

4. 永・酎酸性顆粒八一般二「クローム」及 ビ銅・酎酸性顆粒卜邀キタ異二シ, 肥满七ル 動物二於テモ減少著シ。

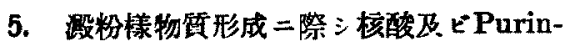

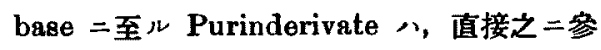
䁌七ザルモノト認ム。

6. 硅曹注射例二於テ八, 队生的耐酸性顆

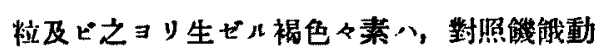
物ノ夫レニ比シテ一般二著シク少数ナリ. 此

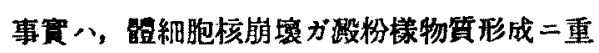
大ナル關係子有ストナスト，Gierke-Asehoff ，說二，有利ナラザ所見ナりト思惟ス。

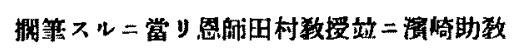
授人御校閲卜御指溥二對シ深諃

\section{女}

2) E. V. Gierke, Path. Anat. von

1) Ertheim, Zieglers Beitr., Bd. 39, S. 158, 1902.

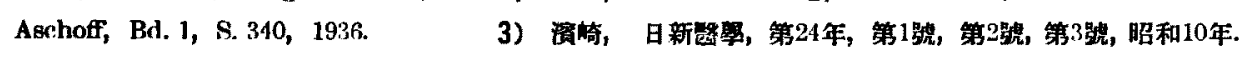

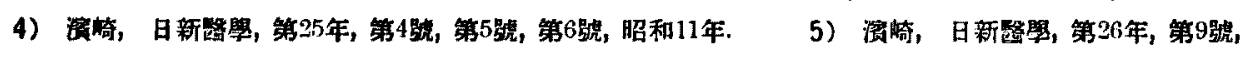

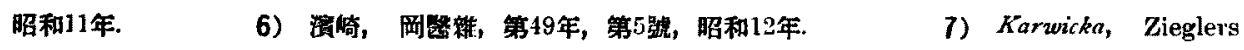
Beitr., Bd. 50, 8. 437, 1911. 8) Kawamura, Die Cholesterinesterverfettung, Jena, 1911. 9）小西，岡㹂雜，第49年，第3號，519頁，昭和12年. 10）Landnu，Dtsch. Med. W., Bd. 39,

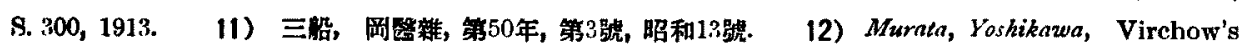
Arch., Bd. 264, 8. 587, 1927. 13) Okuneff, Zieglers Beitr, Bd. 71, 8. 99, $1923 . \quad$ 14) Traina, Zieglers Beitr., Bd. 35, 8. 1, 1904. 


\section{附 圆敦 明}

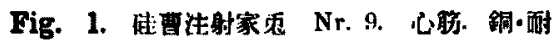

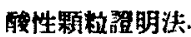

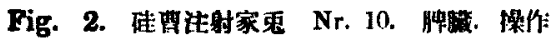

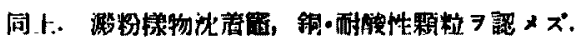

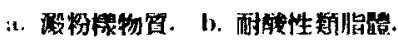

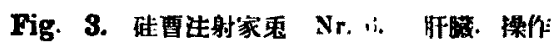

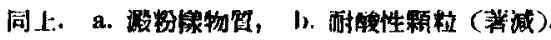

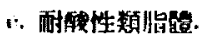

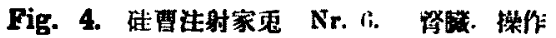

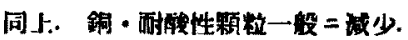

Z. Zwischenstïck, S. Sehaltstiiok, H. Hauptatiöek.

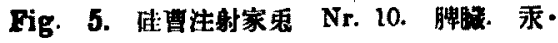

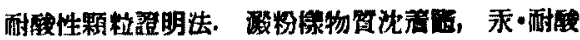

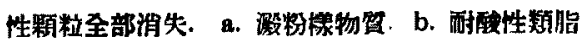

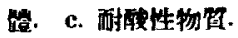

Fig. 6. 理曹注射家鸟 Nr. 10。胃. 推作同 I:. 永·耐酸性颗粒一般二娍少. B. Belegzellen, H. Hautprellen, K. Kerne.

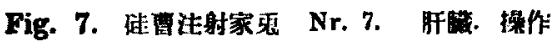

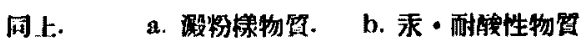
Inkrustation (11, 固定座物).

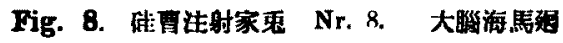

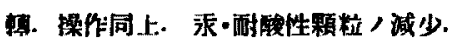

Vergr. Zeiks, $7 \times 40$, K. J. $.90 \mathrm{~cm}$

枿, Fig. B. I $₹, 3 \times 40$ 
三船論文附國

Fig. 1.

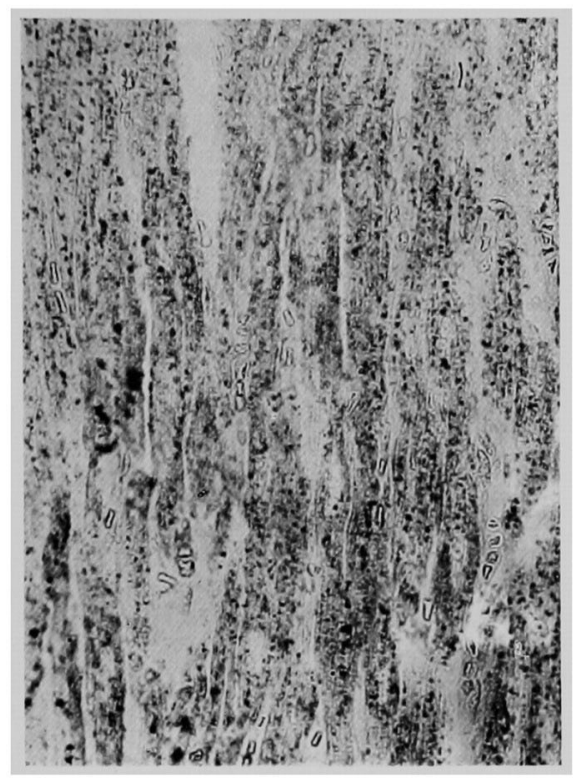

Fig. 3.

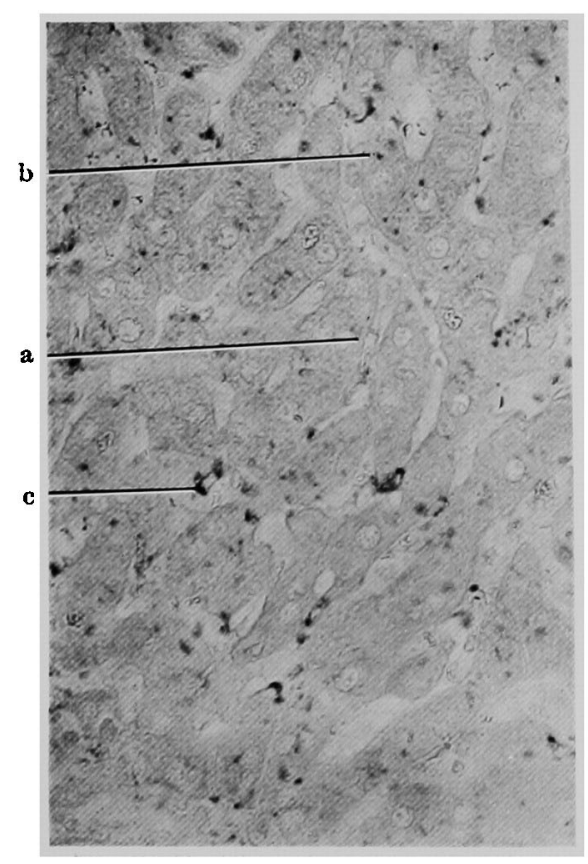

Fig. 2.

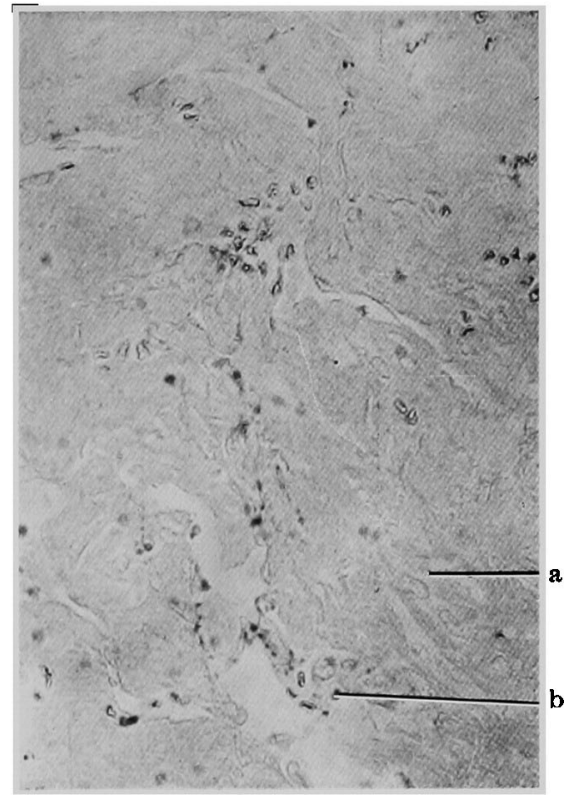

Fig. 4.

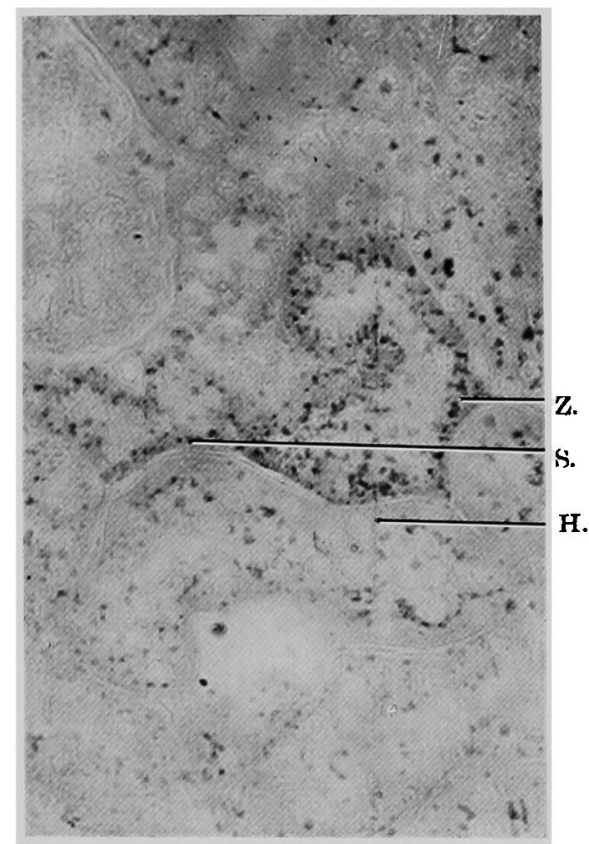




\section{三船論文附圆}

Fig. 5 .

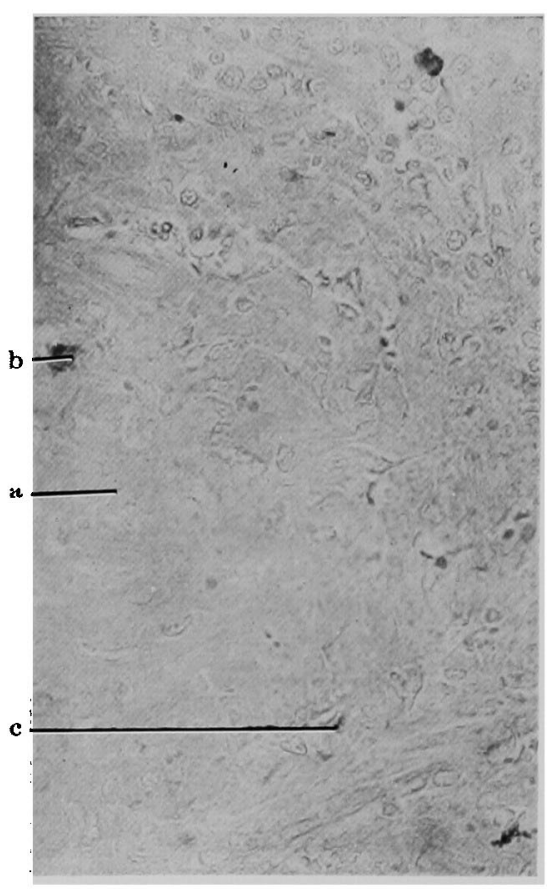

Fig. 7.

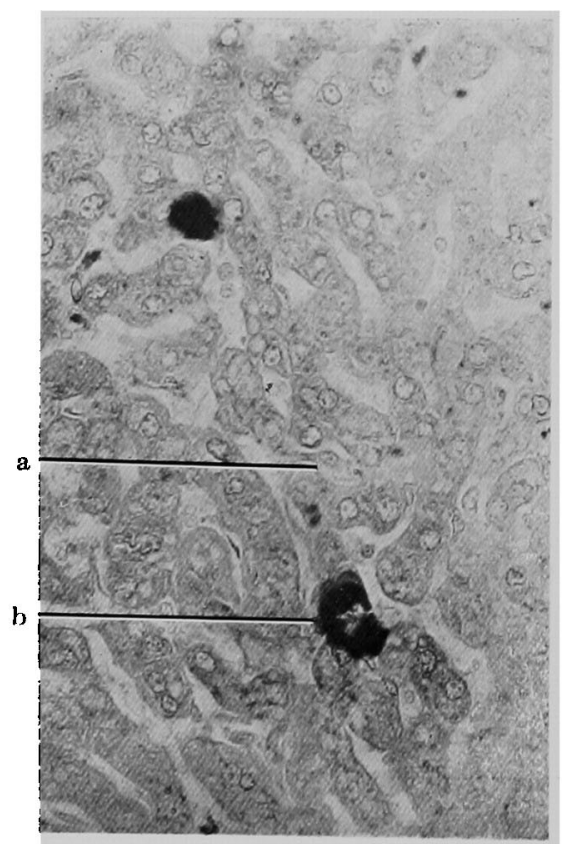

Fig. 6.

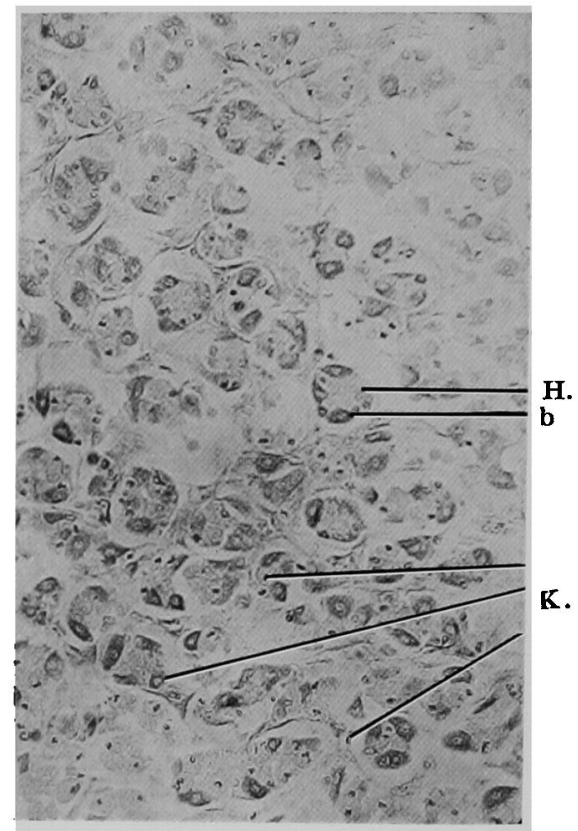

Fig. 8.

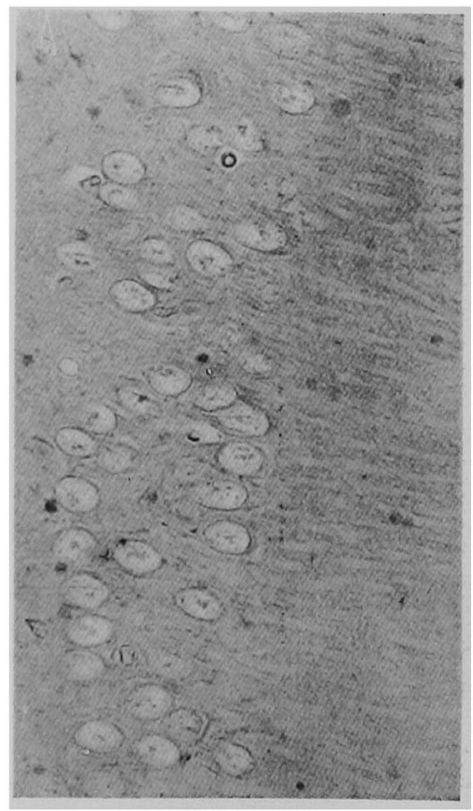

